\title{
PACIFIC NORTHWEST LABORATORY MONTHLY ACTIVITIES REPORT JUNE 1974
}

Division of Production and Materials Management and Hanford Plant Assistance Programs

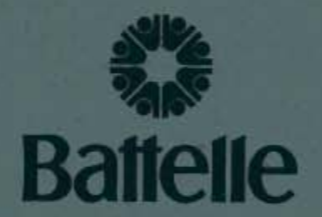

Pacific Northwest Laboratories

Richland, Washington 99352

JULY 1974

Prepared for the U.S. Atomic Energy Commission under Contract AT(45-1):1830 
NOTICE

The report was prepared as an account of work sponsored by the United States Government. Neither the United States nor the United States Atomic Energy Commission, nor any of their employees, nor any of their contractors, subcontractors, or their employees, makes any warranty, express or implied, or assumes any legal liability or responsibility for the accuracy, completeness or usefulness of any information, apparatus, product or process disclosed, or represents that its use would not infringe privately owned rights.

\title{
PACIFIC NORTHWEST LABORATORY \\ operated by \\ BATTELLE \\ for the \\ U.S. ATOMIC ENERGY COMMISSION \\ Under Contract AT(45-1)-1830
}

\author{
Printed in the United States of America \\ Available from \\ National Technical Information Service \\ U.S. Department of Commerce \\ 5285 Port Royal Road \\ Springfield, Virginia 22151 \\ Price: Printed Copy \$4.00; Microfiche \$1.45
}


BNWL-1844

(Special Distribution)

PACIFIC NORTHWEST LABORATORY

MONTHLY ACTIVITIES REPORT

$$
\text { JUNE } 1974
$$

Division of Production and Materials Management and

Hanford Plant Assistance

Programs

by the

Staff of Battelle-Northwest

E. L. Alpen, Director

Ju1y 1974

BATTELLE

PACIFIC NORTHWEST LABORATORY

RICHLAND, WASHINGTON 99352 
TABLE OF CONTENTS

Page

Assistance to Atlantic Richfield Hanford Company - Summary. . . . . . 3

Assistance to Atlantic Richfield Hanford Company. . . . . . . . . . 7

Technical Assistance to the Hanford Plant - Summary . . . . . . . . 20

Technical Assistance to the Hanford Plant . . . . . . . . . 21 


\author{
PACIFIC NORTHWEST LABORATORY \\ MONTHLY ACTIVITIES REPORT \\ DIVISION OF PRODUCTION AND MATERIALS MANAGEMENT \\ AND HANFORD PLANT ASSISTANCE PROGRAMS
}

\title{
ASSISTANCE TO ATLANTIC RICHFIELD HANFORD COMPANY
}

\section{Summary}

\section{PROCESS TECHNOLOGY - RESEARCH DEPARTMENT}

Plutonium Scrap Processing Development

The $\mathrm{NaOH}-\mathrm{Na}_{2} \mathrm{O}_{2}$ fusion technique for converting refractory $\mathrm{PuO}_{2}$ to $\mathrm{HNO}_{3}-$ soluble forms is being tested on dry centrifuge sludge from the plant. The as-received sludge did not ignite during fusion if it was first heated to $800^{\circ} \mathrm{C}$.

Soil Characteristics in $Z$ Trenches

Several additional sediment samples from a 216-Z-1A tile field core well were received for characterization studies. 
Tank Farm Support

Selected soil samples from 200 East and 200 West Area tank farms have been characterized. Desorption curves for each sample were measured using water as well as laboratory prepared dilute waste, early separator slurry and late separator slurry.

\section{Prevention of Accidental Releases}

- Surficial Contamination and Airborne Release Studies

Further data on samples from experiments to determine if $\mathrm{Cs}-137$ is released from contaminated surface materials during heating confirm low release values reported last month.

A computer sub-routine was incorporated into the analysis of airborne release consequences, which plots isopleths of air concentrations at selected heights. State-of-the-art diffusion models which utilize turbulence spectra were adapted for application in this study.

Collection and processing of surface materials from various test plots in and around $U$-pond continued.

Methods to deliver deagglomerated uranium dioxide powder to the wind tunnel are being evaluated for use in studies to determine the potential for airborne release under spill accident conditions.

An isokinetic probe and flow counting chamber was designed and fabricated for measuring $\mathrm{Kr}-85$ which will be used to evaluate the adequacy of gas mixing in ducts to be sampled.

Measurement of the airborne radionuclide concentrations near U-pond showed that suspension of naturally occurring Be-7 and $K-40$ as well as $\mathrm{Zr}-\mathrm{Nb}-95$ and $\mathrm{Cs}-137$ increased as a function of wind speed.

Aircraft concentration measurements of two $\mathrm{SF}_{6}$ plumes were obtained under stable atmospheric conditons for comparison with diffusion model predictions. A computer program for synthesizing "motion pictures" of atmospheric transport over the Hanford site is in the final testing stages.

The analysis of the temperature data for conditions favorable for dust devil formation is nearly complete. Our cooperative dust devil 
observing program is still underway. A technical report on dust devils as related to Hanford operations is being prepared.

- Groundwater Management Studies

Water level data from Hanford wells gathered during the past two quarters has been added to the computer well hydrograph file.

Several computer routines were added to the information retrieval system. Driller's logs were being transferred to magnetic tape storage on an "as time permits" basis.

A version of the PST Model was converted to run on the PDP 11/45 computer.

- Biological Transport Studies

The tissue uptake of $\mathrm{Pu}$ by rats fed tumbleweed treated with $\mathrm{Pu}$ nitrate solution or grown on soil treated with $\mathrm{Pu}$ nitrate solution was about the same whether or not the Pu nitrate solution also contained the chelating agent DTPA.

\section{PROCESS TECHNOLOGY - DEVELOPMENT ENGINEERING DEPARTMENT}

\section{Waste Solidification and Encapsulation}

Satisfactory performance was not attained in laboratory tests of a prototype crusher head for crushing sintered $\mathrm{SrF}_{2}$.

Studies are in progress to develop a laboratory test which will predict plant column performance of different lots of Zeolon (an aluminosilicate cation exchanger) as used for removal of Cs from waste solutions.

An improved procedure for purifying B-Plant $\mathrm{Sr}$ product from $\mathrm{Ba}$ was developed in the laboratory. 
Storage of High-Level Liquid Radioactive Waste

The visible free liquid content of laboratory prepared terminal residual liquor (vacuum crystallizer) was reduced from about 50 to 0 volume precent at ambient temperature in pilot plant scale tests of a wiped film evaporator for concentrating the liquor.

Preparations continued for tests to be conducted in two-foot diameter tanks of cathodic protection for reducing corrosion of storage tank 1 iners by concentrated high-level waste.

Further refinement was made of the point probe ultrasonic detection system for locating cracks in waste storage tank 1 iners.

Tank failure mode analysis studies indicate the failure sequence most significant to producing a release of radioactivity is a near simultaneous failure of the instrumentation system and a single wall tank failure caused by corrosion.

Tank $111 \mathrm{~S}$ was selected for the initial installation of the ultrasonic logging and RF liquid level measurement systems.

Work on external tank leak detection systems involved construction and acquisition of instrumentation. 


\section{ASSISTANCE TO ATLANTIC RICHFIELD HANFORD COMPANY}

\section{PROCESS TECHNOLOGY - RESEARCH DEPARTMENT}

\section{Plutonium Scrap Processing Development}

Recovery of Plutonium from Process Wastes

(J. A. Partridge, Chemical Development Section and

E. J. Wheelwright, Applied Chemistry Section)

The objective of these studies is to develop a $\mathrm{NaOH}-\mathrm{Na}{ }_{2} \mathrm{O}_{2}$ fusion technique for converting refractory $\mathrm{PuO}_{2}$ present in process wastes such as incinerator ashes to $\mathrm{HNO}_{3}$-soluble plutonium for recovery.

Analytical data are now available on a series of tests performed on samples from a can of regular incinerator ash received from ARHCO. A portion of the ash was leached at $70-80^{\circ} \mathrm{C}$ with $12 \mathrm{M} \mathrm{HNO}_{3}-0.3 \mathrm{M} \mathrm{HF}$ to produce a so-called "processed ash". About 25 percent of the Pu present in the ash was solubilized during the leaching.

In these tests, ash and a $\mathrm{NaOH}-\mathrm{Na}_{2} \mathrm{O}_{2}$ mixture were fused at $600^{\circ} \mathrm{C}$ for one hour while contained in a mild steel container. The melt was cooled and the container as well as the fusion mixture was dissolved in dilute $\mathrm{HNO}_{3}$. Parameters varied were the $\mathrm{NaOH}$ to $\mathrm{Na}_{2} \mathrm{O}_{2}$ weight ratio and the ratio of ash weight to weight of $\mathrm{NaOH}-\mathrm{Na}_{2} \mathrm{O}_{2}$. In most tests the $\mathrm{NaOH}$ to $\mathrm{Na}_{2} \mathrm{O}_{2}$ weight ratio was one. With $3.5 \mathrm{~g}$ of this mixture to $1 \mathrm{~g}$ of ash, recovery of $\mathrm{Pu}$ in the dilute $\mathrm{HNO}_{3}$ was 91 percent for unleached ash and 97 percent for the leached ash. As the ratio of fusion mixture to ash was decreased, the recovery of $\mathrm{Pu}$ also decreased and approached 0 at a ratio of one. In a test at a $\mathrm{Na}_{2} \mathrm{O}_{2}$ to $\mathrm{NaOH}$ ratio of two, the mixture ignited as it was heated. The weight of solids left after dissolving the fused mixture in dilute $\mathrm{HNO}_{3}$ ranged from 25 to $65 \mathrm{wt} \%$ of the weight of ash used.

Currently tests on dry centrifuge sludge are in progress. When the as-received sludge was fused with $\mathrm{NaOH}-\mathrm{Na}_{2} \mathrm{O}_{2}$, ignition and spewing of material from the container occurred. When the sludge was heated to $800^{\circ} \mathrm{C}$ for one hour prior to fusion with $\mathrm{NaOH}-\mathrm{Na}_{2} \mathrm{O}_{2}$, ignition did not occur. 
Soil Characteristics in $Z$ Trenches

Characterization of 216-Z-1A Tile Field Sediments

(L. L. Ames, Water and Waste Management Section)

Several additional sediment samples from a new core well in the 216-2-1A tile field were received during June for characterization. These are being stored in a gloved box pending resumption of work on this study after July 1. They will then be dried and impregnated with plastic for mineral and autoradiographic studies.

Tank Farm Support

Hydraulic Properties of Tank Farm Sediments

(S. J. Phillips, Resources Systems Section)

Selected sediment samples from 200 East and 200 West Area Tank Farms have been characterized as to saturated hydraulic conductivity, saturated moisture content, bulk and particle density, capillary pressure vs. saturation, capillary pressure vs. relative hydraulic conductivity, and relative hydraulic vs. saturation. Water and laboratory prepared dilute waste, early separator slurry, and late separator slurry waste solutions were used in the analysis. Additional sediment samples from 200 West Area are currently being analyzed for the same parameters. These analyses are part of the tank farm sediment characterization program. 


\section{Prevention of Accidental Releases}

\section{- Surficial Contamination and Airborne Release Studies}

B-C Crib Studies

(J. Mishima and L. C. Schwendiman, Particulate and Gaseous Waste Research Section)

Potential Airborne Release of Contaminated Surface Materials by Heating

In laboratory studies the airborne release of Cs-137 during heating of contaminated surface materials as measured in four additional experiments (three at $200^{\circ} \mathrm{C}$ and one at $400^{\circ} \mathrm{C}$ ) continues to be smal1. The source materials in all 16 experiments done to date were all dried, flammable materials collected from Zone 1 of the B-C Control Area. In all cases, measurable quantities of Cs-137 were found in the solid residues from the ashing (from 57 to $150 \%$ of the calculated Cs-137 in the source) with detectable but not quantifiable amounts in the bubbler and filter samples. A maximum of $4 \pm 2 \%$ of the Cs-137 present in the source was found on the filter when the source, $450 \mathrm{dpm}$ of Cs-137 in $21.6 \mathrm{~g}$ of sagebrush, was heated to $200^{\circ} \mathrm{C}$. Measurements of $\mathrm{Sr}-90$ in all samples from the 16 experiments are in progress.

\section{Safety Analysis of B-C Crib Area Contamination}

A computer model is being developed to calculate the potential for airborne distribution of material resuspended from the contamination pattern in the B-C Crib Area. To enhance the interpretability of the computer output, a sub-routine has been added which plots isopleths of air concentration at a selected height. This routine was tested by utilizing it to plot isopleths surveyed by EG\&G. The two patterns matched very well.

Work was begun on the adaptation of a state-of-the art diffusion model for use in conjunction with the B-C crib resuspension model. The model selected for adaptation utilizes atmospheric turbulence spectra to estimate diffusion parameters for dispersion of material from elevated sources. The original model has been modified to accept ground level sources. An additional modification is being tested which accounts for the rise of the center of the mass of the airborne material as it travels downwind. Further work is planned to optimize the model using measured diffusion data. 
U-Pond Contamination Studies

(L. C. Schwendiman, J. Mishima, Particulate and Gaseous Waste Research Section) Collection and processing of surface materials from $1 \mathrm{~m}^{2} \times 1 \mathrm{~cm}$ deep plots in the area around $U$-pond continues. The various samples of materials collected will be analyzed to determine if they contain radioactive constituents.

Potential Airborne Release of Radioactive Materials Under Postulated Accident Conditions

(J. Mishima, L. C. Schwendiman, Particulate and Gaseous Waste Research Section)

As part of a study to measure the airborne release of powders spilled into flowing air, various methods of delivering ball-milled uranium dioxide into the wind tunnel are being evaluated. Even with drying and aeration, the powder tends to agglomerate. The most promising method tried thus far is a magnetically agitated metal trough (Erie Magnetic Feed). The rate is low and inconsistent in tests thus far but the device appears to produce a relatively deagglomerated powder. Release rates will also be determined for a similar mass of the same powder in a single drop.

A method to measure the amount of depleted uranium dioxide powder by comparison with counting rates of known quantities of the same powder in a standard configuration is under consideration.

Characterization of Radioactive Particles in Process Gaseous Effluents (J. Mishima and L. C. Schwendiman, Particulate and Gaseous Waste Research Section)

One criteria for a suitable gas and airborne particle sampling location for a flowing gas stream is homogeneity -- a well mixed stream. Methodology for validating the adequacy of gas mixing from the last insertion to sampling point in process gaseous effluent is in progress. $\mathrm{Kr}-85$ is an inert gas not commonly found in most process gaseous effluents. Since $\mathrm{kr}-85$ is radioactive, relatively sensitive counting methods can be used to measure the quantity present. A flow chamber with a thin-window gas tube detector and an isokinetic probe capable of various depths of insertion have been designed and fabricated for demonstration in the 234-5Z plant stack. 
Resuspension from Contaminated Surfaces -- Field Studies

(G. A. Sehme1, F. D. Lloyd and L. C. Schwendiman, Particulate and Gaseous waste Research Section)

Results from radionuclide concentration measurements have been received for the January 16 - February 8, 1974 sampling experiment at the U-pond. Particle impactor cowl sampling systems were located on one tower at the 1, 3, 6, 10 and $20 \mathrm{ft}$ heights. Three sampling systems were located at each height. One sampled during wind speeds of 3 to $8 \mathrm{mph}$, the second during wind speeds from 8 to $13 \mathrm{mph}$, and the third during wind speeds greater than $13 \mathrm{mph}$. Winds from all directions were sampled. Airborne concentrations of Be-7, K-40, $\mathrm{Zr}-\mathrm{Nb}-95$, and $\mathrm{Cs}-137$ a 11 increased non-linearly with increasing wind speed. Concentrations were from 20 to 42 times greater during winds exceeding $13 \mathrm{mph}$ than the concentrations observed during winds of 3 to $8 \mathrm{mph}$. No concentration measured exceeded $2.3 \times 10^{-12} \mu \mathrm{Ci} / \mathrm{cm}^{3}$. Data analysis is continuing.

Some difficulty with filter media was experienced; filters from a new shipment were cracking in the field. Filters from a replacement order are now in use.

Both U-area and B-C area experiments are continuing with sampling as a function of wind speed and wind direction.

Wind Trajectory Studies

(L. L. Wendell and W. F. Sandusky, Atmospheric Physics Section)

In this reporting period two early morning aircraft tracking experiments were conducted during stable atmospheric conditions. These experiments which involve sampling an $\mathrm{SF}_{6}$ plume while tracking a constant volume balloon, alorg with similar ones conducted previously, provide data for stable, neutral, and unstable conditions. Concentrations measured in these plumes will be compared to results obtained from calculations using the transport and dispersion model.

Conversion of the trajectory plotting program to produce a version which will generate motion pictures of transport over the Hanford site is now complete. Test plots of selected frames on microfiche have been completed. Testing of the software and operation of the $16 \mathrm{~mm}$ camera on CDC's FR 80 plotter can now begin.

A d'raft interim report entitled, Wind-Flow Patterns and Computed Air Trajectories Over the Hanford Reservation has been completed and will be distributed for comment. 
A light, inexpensive temperature sounding device was borrowed from the Atmospheric Sciences Group of the Argonne National Laboratories in Chicago for feasibility testing in the constant volume balloon experiments.

Significance of Dust Devils and Other Anomalous Winds (M. M. Orgill and L. C. Schwend?man, Particulate and Gaseous waste Research Section)

This study is undertaken to determine the potential seriousness, from a resuspension standpoint, of dust devils and other unusual wind conditions.

Analysis of the temperature data from the 122-meter meteorological tower is essentially complete.

The pilot observing program for dust devils is still underway; approximately 16 dust devils were observed during the past 30 days. We will attempt to obtain photographic records of typical Hanford dust devils for additional study.

A technical document concerning dust devils and their significance in relation to Hanford operations is under preparation.

- $\quad$ Groundwater Management Studies

Groundwater Model and Data Storage and Retrieval (K. L. Kipp, Resources Systems Section)

All water level measurements taken in the Hanford wells during the two past quarters have been added to the hydrograph files of the computer information retrieval system.

A version of the Partially Saturated Transport (PST) Model has been converted to the PDP $11 / 45$.

Several new computer routines necessary to handle the large volume of data assembled for entry to the information storage and retrieval system have been written for the PDP 11/45. As time permits the driller's logs are being transferred to magnetic tape. Preliminary computer routines for retrieving and displaying selected data have been written. 
Field Measurements and Monitoring Assistance

(K. L. Kipp, Resources Systems Section)

Moisture content of the soils in the lysimeters was monitored with the neutron probe on June 11 and again between June 24 and 27, 1974. On the 1atest measurements the moisture front was closely defined by taking small incremental steps between standard measurement points. In the closed lysimeter the moisture front is near $12.5 \mathrm{ft}$ with the highest readings from 10 to $12 \mathrm{ft}$. In the open lysimeter the moisture front is between 17 and $18 \mathrm{ft}$; the highest readings near $15 \mathrm{ft}$.

An updated well location map for the Hanford project was completed and printed during the past month.

Miscellaneous

(K. L. Kipp, Resources Systems Section)

We11 maintenance work to upgrade the monitoring program continues. Eighteen more wells have been cleaned out and reperforated.

\section{- Biological Transport Studies}

Biological Interactions

(R. C. Routson, Environmental Chemistry Section)

In cooperation with a plant and animal census site study, surface soil chemical and physical properties from four sites near the BC crib and the Redox pond areas were measured. Surface soil properties measured at all sites include: 1) particle size analysis; 2) soil pH; 3) conductivity of the saturation extract; and 4) organic matter content. In addition, the fertility status ( $N, P, K)$ of composites from two depths at the two $B C$ crib sites were measured to provide direct soil input data for the plant studies. All of the above analyses were completed during the study period.

Work continued on the study of the food chain transfer of $\mathrm{Pu}, \mathrm{Am}$ and $\mathrm{Cm}$ from tumbleweed tissue to a reference animal (rat). Comparisons are being made of the gastrointestinal uptake of these transuranic (TRU) elements from tumbleweed grown on soil contaminated with the TRU elements in nitrate solution with that from tumbleweed grown on soil contaminated with TRU element nitrate-DTPA solution. 
Gavage feeding of rats has been completed for all treatments and all analyses for Pu are completed.

The presence of DTPA in the plutonium nitrate did not increase the absorption of plutonium in rat tissue. The total absorption (tissue and urine) was increased by DTPA but the increase was eliminated from the carcass by increased urinary excretion of $\mathrm{Pu}$ when added with excess DTPA. Although there were significant differences among animals in each group, the data indicate that the $\mathrm{Pu}$ taken up by plants was similar to the Pu nitrate treatment. A plausible explanation is that the DTPA in excess of the complex is insufficient to stabilize the Pu-DTPA complex in the intestinal environment or that the PU-DTPA complex is not present in plants.

\section{PROCESS TECHNOLOGY - DEVELOPMENT ENGINEERING DEPARTMENT}

Waste Solidification and Encapsulation

Strontium Fluoride Encapsulation

(B. Norton, Chemical Development Section)

Continued laboratory testing of a prototype crusher head for crushing sintered $\mathrm{SrF}_{2}$ has failed to define conditions for satisfactory performance. The head will not handle sintered material which varies in crushing characteristics. Modifications to the filtering and sintering process to produce a more uniform sintered product is being considered.

A self-heating insulated container for drying $\mathrm{SrF}_{2}$ will be fabricated and tested in the laboratory.

Cesium Ion Exchange Studies

(J. A. Partridge, Chemical Development Section)

Past experience with the adsorption of cesium ion by Zeolon, a synthetic alumino-silicate cation exchanger manufactured by the Norton Company, has indicated some of the exchange properties vary from lot to lot of the exchanger. A study was initiated to investigate differences in alkali metal ion selectivity, capacity and exchange kinetics among various lots of recently-produced Zeolon. The objective is to develop a laboratory test which can be used to predict differences in column performance of different shipments of Zeolon used in plant columns. The three above exchange properties are being determined on three different recently-produced lots of Zeolon. 
Strontium-Barium Separation Flowsheet Development

(L. A. Bray, Applied Chemistry Section)

In prior laboratory studies a flowsheet for separation of $\mathrm{Ba}$ from $\mathrm{Sr}$ in B-Plant Sr product was developed. This process involved formation of sulfate precipitation at $10 \mathrm{w} \mathrm{pH}$, digestion, hydroxide precipitation at $\mathrm{pH} 10$ and washing the precipitate with water. In typical results, $3-4 \%$ of the $\mathrm{Sr}$ and ca. $75 \%$ of the $\mathrm{Ba}$ was carried on the precipitate which was dissolved in acidic HEDTA solution and recycled to B-Plant solvent extraction.

An alternate process was developed in the laboratory which provides better $\mathrm{Sr}$ recovery and less $\mathrm{Ba}$ in the recycled material. The water-washed sulfate hydroxide precipitate (above) is methasized with $\mathrm{NaOH}-\mathrm{Na}_{2} \mathrm{CO}_{3}$; solid and liquid are separated and the liquid is sent to waste. The solid is dissolved in $\mathrm{HNO}_{3}$ and oxalic acid is added to precipitate $\mathrm{Ba}$ as oxalate. After digestion, the solid and liquid are separated and the supernatant liquid is recycled to solvent extraction. The oxalate precipitate may be sent to waste.

In laboratory tests with B-Plant product as feed solution, a Sr product was decontaminated from $\mathrm{Ba}$ by a factor of 4 , recycle to solvent extraction contained $17 \%$ of the $\mathrm{Ba}$ and $2.2 \%$ of the $\mathrm{Sr}$ and material sent to waste contained $55 \%$ of the $\mathrm{Ba}$ and only $0.1 \%$ of the $\mathrm{Sr}$.

\section{Storage of High-Level Liquid Radioactive Waste}

Task 2 - Characterization of Stored Wastes

Wiped Film Evaporation of Residual Liquors

(R. D. Dierks, Process Demonstration Section)

High-level liquid radioactive wastes at Hanford are currently being reduced in volume by repeated evaporation and fractional crystallization steps in which some water is removed from the waste and some of the dissolved salts are precipitated. With each step the composition of the supernatant liquor changes; the fraction of the more soluble salts increases and the boiling temperature of the liquor increases. With a given piece of equipment, these steps continue until the boiling point of the liquid and the temperature of the heating medium (steam) become so nearly the same that little, if any, additional volume reduction is effected and a terminal residual liquor is encountered.

Two experiments were conducted with a wiped film evaporator to evaluate the feasibility of further reducing the water content of the terminal residual liquor resulting from the presently used vacuum crystallizer system. The evaporator used was a horizontal Artisan-Kontro unit, with a tapered barrel about a foot in diameter and with a $5 \mathrm{ft}^{2}$ heat transfer surface. The unit was steam heated, with a maximum steam pressure of 120 psig available. Adjustable 
paddles maintained a $1 / 32-i n$. thick film of material on the heat transfer surface. The laboratory prepared residual liquor feed was introduced into the evaporator at $130^{\circ} \mathrm{C}$, just under its initial boiling point of $134^{\circ} \mathrm{C}$.

During the two experiments the feed rate to the evaporator was maintained at 15,30 , and $60 \mathrm{\ell} / \mathrm{hr}$ and the steam pressure to the heating jacket was varied in discreet increments from 30 to $120 \mathrm{psig.} \mathrm{At} \mathrm{each} \mathrm{feed} \mathrm{flow} \mathrm{rate} \mathrm{as} \mathrm{the}$ jacket pressure was increased, the product concentration, temperature, and viscosity would increase. In all cases, the product was a liquid, with perhaps a small amount of suspended solids in the more concentrated samples. On cooling to ambient temperature, the visible free liquor varied from perhaps 50 to $0 \%$ by volume as the water content decreased from perhaps 40 to $25 \%$ by weight.

The overall heat transfer coefficient for the unit was surprisingly low (50-175 BTU/hr- ${ }^{\circ} \mathrm{F}-\mathrm{ft}^{2}$ ) and highly dependent on the solids content of the product as well as on the feed rate to the evaporator.

A vitreous ename $1-1$ ined magnetic flow meter was attacked by the hot $\left(80^{\circ} \mathrm{C}\right)$ caustic feed solution. Further experiments with the evaporator will be delayed until a teflon-lined meter can be installed and calibrated.

Task 3 - Tank Integrity

Corrosion Studies

(R. F. Maness, Corrosion Research and Engineering Section)

Studies pertinent to the cathodic protection of underground tank liners were continued. Polarization of mild steel specimens exposed to simulated solidified waste $\left(15 \% \mathrm{H}_{2} \mathrm{O}\right)$ was determined as a function of current density at $60-70^{\circ} \mathrm{C}$ using a platinum anode. The open circuit potential was about - $650 \mathrm{mv}$ (vs SCE). A plot of $\log$ current density vs potential approximated a straight line; true Tafel behavior was not observed, however. The current density required to effectively inhibit corrosion (about $10 \mu \mathrm{amp} / \mathrm{cm}^{2}$ ) requires a shift in potential of about $285 \mathrm{mv}$. A rule of thumb in the cathodic protection of buried pipe lines requires a polarization of $300 \mathrm{mv}$. These data will be used to determine current distribution as a function of anode placement when a small (2 ft-dia.) tank becomes available. It will be convenient to make initial current distribution studies with aqueous solutions which have a resistance approximating that of solidified waste with varying amounts of 
water. The specific resistance of a number of dilute $\mathrm{NaOH}-\mathrm{NaNO}_{3}-\mathrm{NaNO}_{2}$ systems was determined and mild steel polarization was evaluated in two of these systems (45 and $250 \mathrm{ohm}-\mathrm{cm}$ ). In both solutions a current density of $10 \mu \mathrm{amp} / \mathrm{cm}^{2}$ produced a polarization of about $300 \mathrm{mv}$. Initial studies of current distribution vs anode composition and placement will be made with these solutions.

There is some concern for the possibility of caustic cracking of mild steel 1 iners exposed to solidified waste. Open circuit potentials of mild steel electrodes exposed to $10-40 \% \mathrm{NaOH}$ solutions were determined at temperatures ranging from $25-75^{\circ} \mathrm{C}$. None were in the published range $(-1150$ to $-850 \mathrm{mv}$ vs SCE) for caustic cracking. Air sparging and additions of $\mathrm{CrO}_{3}$ and $\mathrm{H}_{2} \mathrm{O}_{2}\left(\mathrm{C}^{-5}\right.$ to $10^{-2} \mathrm{M}$ ) did not produce potentials within the cracking range. Other systems will be evaluated.

U1trasonic Detection of Stress Cracks in Tanks (G. J. Posakony, Nondestructive Testing Section)

Refinement of the "point probe" ultrasonic inspection device is continuing. The current probe design provides good sensitivity, is extremely rugged, and is adaptable to a field inspection system. Laboratory tests with the "point probes" indicate that stress corrosion cracks in steel plate material can be detected beneath a 1/4 in. thickness of asphalt impregnated felt material. The asphalt impregnated material is expected to be present between the concrete encasement and the steel tank wa11. Presence of this material should not seriously affect the detection of stress corrosion cracking in the steel wall.

Task 4 - Failure Mode Analys is (P. A. Crosetti and R. I. Smith, Safety Analysis Section)

Studies of the high heat liquid waste tank fualt tree model have continued. Branches which model the transfer piping systems and the tank ventilation systems have been incorporated into the tree. Processing of the tree through Program SAFTAC has demonstrated that the failure sequence most significant to producing a release of radioactivity from the tank is a near simultaneous failure of the instrumentation system and a single wall tank failure due to corrosion attack.

As a result of the above, considerable effort has gone into completion of the analysis of the tank instrumentation system and data handling system. 
Modifications have been made to the tree model incorporating the most recent field improvements and the model has been prepared for processing through Program SAFTAC. Initial studies are expected to be completed by month's end.

\section{Task 6 - Leak Detection}

6.1 - Liquid Level Measurement

(G.J. Posakony, Nondestructive Testing Section)

A final review meeting has been held with ARHCO personnel to obtain the latest information regarding FIC system operations and the status of ongoing modifications. The information obtained is being incorforated into the final report on the FIC system audit. Issuance of the final report has been postponed until mid-July to permit inclusion of selected portions of the fault-tree analysis data.

Preparations for in-tank installation of a breadboard ultrasonic logging system are continuing. In a recent meeting with ARHCO, Tank 1115 was selected for the initial installation of the ultrasonic logging and RF measurement systems. This tank is presently being filled with liquid wastes which will be converted to a semi-solid slurry in the coming months. The tank contains an FIC gage which will allow comparison of the three measurement systems under dynamic in-tank conditions. Three ultrasonic $\log$ "wet wells" are to be installed in the waste tank by ARHCO in existing risers. Ultrasonic transducers to be used in the field tests are currently being assembled and should be ready by the end of June.

A manual transducer positioning apparatus has been designed and is currently being assembled. A variable speed motor drive system is also being assembled for use with the transducer positioning system. It will be incorporated into the system at a later date to allow simultaneous positioning of two transducers and to permit more meaningful strip chart recordings of the data.

The ultrasonic logging breadboard electronics package has been checked out in the laboratory with the laboratory transducers. Final 
laboratory tests on the entire breadboard ultrasonic logging system will get underway upon completion of the system transducers. The system should be available for a mid-July installation, assuming the "wet wells" are in place at that time.

Work continued on the planning and design of the data system interfacing necessary for in-tank tests of the RF-type liquid level system.

Although laboratory tests have shown that the temperature sensitivity and temperature stabilization system used in the manufacturer's design causes a periodic variation of \pm 100 units in a span of $10^{5}$, the accuracy is expected to be improved by observing span and zero changes in each data batch taken.

Preliminary design is for a solid-state sequencing drive with a capability of scanning up to nine antennae, seven of which may be in other tank locations or external to the tank for external leak detection. Antenna number and a six-figure numerical value of the reading will be recorded digitally.

6.3 - Externa1 Methods

(M. R. Kreiter, Process Evaluattion Section)

Work was directed toward construction and acquisition of instrumentation which will increase both the sensitivity and speed with which data can be taken on the we11-to-well and tank-to-well impedances on the three tanks designated as a leaker, a suspected leaker and a nonleaker. Contacts with four manufacturers' representatives were made to request statements of capability regarding the manufacture of system segments or components which would provide automatic scanning with alarm or computer input capability utilizing measures of both capacitance and resistance. 


\section{TECHNICAL ASSISTANCE TO THE HANFORD PLANT}

\section{Environmental Evaluations \\ (J. P. Corley, Environmental Evaluations Section)}

The last of the results of the ARMS aerial survey of April 1974 were received from EG\&G, Inc. The surveyed area below McNary Dam showed one smal1 area slightly above background. This area is now under water due to the increased river flow, as is much of the island and shoreline area for which the ARMS survey showed radiation levels above background. As usual during high river flows, radiation levels at monitored shoreline locations were generally lower in June than earlier in the year. The one shoreline location that showed increased radiation levels was the $\mathrm{N}$-Springs location, where a shoreline dose rate of $0.06 \mathrm{mR} / \mathrm{hr}$ (as compared to $0.045 \mathrm{mR} / \mathrm{hr}$ early in May) was measured about two weeks after the $\mathrm{N}$-Reactor shutdown.

Special fallout sampling of air, milk, and vegetation and special dosimetry was initiated following a reported foreign nuclear weapons test on June 18, 1974. As of June 28, 1974, no positive evidence had been seen of regional fallout in these samples, although high-volume air sampling by Radiological Chemistry Section temporarily showed traces of radionuclides attributed to this test about a week after the event.

Routine surveys of ground plots, roads, and retired waste disposal sites showed no unusual conditions during the month.

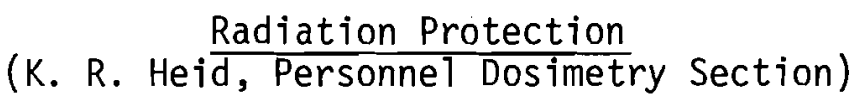

A new technique for estimating the effectiveness of diethylenetriaminepentaacetic acid (DTPA) treatment for the removal of plutonium was developed.

UST began work which is expected to lead to the ability for them to provide the plutonium to americium ratio as well as the amount of these radionuclides in fecal and urine samples. They also have techniques, developed at our request, for making analysis for "total actinides" in fecal and urine samples.

We now have a micro-fich file by payroll number, name, and Social Security number for every person who has worked at Hanford since 1945. 


\section{Radiation Standards and Engineering \\ (J. M. Selby, Radiation Standards and Engineering Section)}

Approval of the preprocurement plan for the purchase of new beta-gamma survey meters has been received from the AEC. A list of potential suppliers has been prepared and the bid invitations should be in the mail shortly.

Control circuitry for the Cf-252 fast neutron exposure facility has been designed and is now being installed. Preliminary measurement of thermal neutron flux in the $\mathrm{D}_{2} \mathrm{O}$-moderated exposure facility indicates dose rates may be as much as 30 times as high as may be obtained in the sigma pile.

The two MeV Van de Graaff continues to cause problems. The component that appears to be responsible is a new type electron source which was installed to permit pulsed operation of the machine. Solutions to the problem are being explored.

A new counting system has been received. The system will be used with the Long Counter to calibrate our neutron sources and exposure facilities. Calibrations will be by cross comparison with our 80 gram PuBe neutron standards.

\section{(E. H. Phinney, Synoptic Meteorology Section)}

Meteorological services, viz., weather forecasts and observations and climatological services were provided to plant operations and management on a routine basis.

June 1974

Type

Production Forecasts:

General Forecasts:

Special Forecasts:

Other Requests:

Publications Distributed:

Number of Calls Processed by Code-A-Phone: Total Service Actions:
No. Made \% Reliability

60

83.1

60

88.2

228

71.1

4,055 


\begin{tabular}{l}
$\begin{array}{l}\text { Copy } \\
\text { Number }\end{array}$ \\
\hline $1-3$ \\
4 \\
$5-6$ \\
7 \\
$8-9$ \\
10 \\
11
\end{tabular}
OFF-SITE DISTRIBUTION
$\underline{\text { USAEC, Washington - Division of Production }}$
USAEC Headquarters J. L. Liverman, AGMBER
Technical Information Center, Oak Ridge, Tennessee
Savannah River AEC Operations Office

E. I. du Pont de Nemours \& Company

Savannah River Laboratory

$\frac{\text { AEC Idaho Operations Office }}{\text { K. K. Kennedy }}$

Allied Chemical Corporation, Idaho Falls J. A. Buckham

$\underline{\text { ON-SITE DISTRIBUTION }}$

AEC Richland Operations Office

12

13

14

15

16

17

0. J. Elgert

A. G. Fremling

P. G. Holsted

B. J. Melton

R. B. St. John

F. R. Standerfer

United Nuclear Industries, Inc.

\section{8}

\section{9}

20

21

22

23

24

25

26

P. A. Carlson

C. D. Corbit

R. E. Dunn

A. E. Engler

C. Harrington

R. T. Jessen

A. R. McGuire

N. R. Miller

J. T. Stringer/H. F. Tew

Atlantic Richfield Company

27 G. E. Backman

28 G. L. Borsheim

29 D. J. Brown

30 L. E. Bruns

31 M. H. Campbel1

32 R. E. Felt

33 R. D. Fox

34 R. G. Geier

35 D. G. Harlow

36

W. M. Harty
Copy

Number

37

38

39

40

4.1

42

43

44

45

46

47

48

49

50

51

52

53

54

55

56

57

Westinghouse Hanford Company

58

59

G. J. Alkire

A. G. Blasewitz

H. H. Hopkins

W. P. Ingalls

R. E. Isaacson

H. Jensen

L. M. Knights

W. D. Luen ing

C. W. Malody

T. R. McKenzie

B. J. McMurray

G. A. Nicholson

G. C. Oberg

J. V. Panesko

K. R. Price

W. W. Schulz

H. P. Shaw

A. E. Smith

R. E. Smith

G. T. Stocking

M. J. Szul inski

W. J. Van Slyke

D. D. Wodrich 
Number

\section{ON-SITE DISTRIBUTION (continued)}

\section{Battelle-Northwest}

$\begin{array}{ll}60 & \text { R. E. Burns } \\ 61 & \text { E. D. Clayton } \\ 62 & \text { J. P. Corley } \\ 63 & \text { J. R. Eliason } \\ 64 & \text { R. F. Foster } \\ 65 & \text { T. R. Garland } \\ 66 & \text { K. M. Harmon } \\ 67 & \text { H. L. Henry } \\ 68 & \text { G. Jansen } \\ 69 & \text { J. H. Jarrett } \\ 70 & \text { J. L. McElroy } \\ 71 & \text { J. E. Minor } \\ 72 & \text { R. E. Nightingale } \\ 73 & \text { D. E. Olesen } \\ 74 & \text { W. D. Richmond } \\ 75 & \text { W. H. Rickard } \\ 76 & \text { R. C. Routson } \\ 77 & \text { L. C. Schwendiman } \\ 78 & \text { G. A. Sehmel } \\ 79 & \text { A. J. Shuckrow } \\ 80 & \text { C. L. Simpson } \\ 81 & \text { W. G. N. Slinn } \\ 82 & \text { R. I. Smith } \\ 83 & \text { H. H. Van Tuyl } \\ 84 & \text { B. E. Vaughan } \\ 85 & \text { D. G. Watson } \\ 86 & \text { R. E. Wildung } \\ 87 & \text { R. K. Woodruff } \\ 88 & \text { J. R. Young } \\ 89-91 & \text { Technical Information Files }\end{array}$

